Original article

\title{
Urban agglomerations and transformations of medium-sized towns in Poland
}

\author{
Anna Runge \\ Department of Economic Geography, Faculty of Earth Sciences, University of Silesia, Będzińska Str. 60, Sosnowiec, Poland \\ E-mail address: anna.runge@us.edu.pl
}

\begin{abstract}
This analysis investigates medium-sized towns in Poland, i.e. those with a population between 20-100 thousand, located up to $100 \mathrm{~km}$ away from the main city of the agglomeration. The aim of this article is to compare the level of socio-economic development of Polish towns depending on their location in relation to the main city in the largest agglomerations in 1998 and 2013. Three zones of distance from the main city of each agglomeration have been taken into consideration: a. the inner zone, reaching up to $25 \mathrm{~km}$ from the main city; b. the outer zone located at a distance of 25 to $50 \mathrm{~km}$ from the main city, and c. the peripheral zone, located at a distance of 50 to $100 \mathrm{~km}$ from the main city and including the medium-size towns located outside the agglomeration system. This analysis of the distribution of medium-sized towns and their level of socio-economic development has shown various levels of changes which depend on the distance from the main city of the agglomeration. In 1998, the highest level of development of the medium-sized towns was recorded in towns outside of these agglomeration systems, i.e. those located most remotely from the main city (peripheral zone). Most of the medium-sized towns are situated at a distance of 50-100 km from Warszawa, Kraków, Łódź, Lublin, Gdańsk and have developed their own local, or even regional labour markets and some of them have even provided administrative functions in the past as voivodeship capitals. Only in the Poznań agglomeration, the level of development of medium-sized towns was higher in the immediate surroundings of the main city $(25 \mathrm{~km})$. The medium-sized towns in all zones of the distance from the main city in the Wrocław agglomeration represented a similar level of development. By 2013, the level of development of the medium-sized towns in the peripheral zone in all investigated settlement systems had decreased, with a significant improvement in the level of development of the towns in the immediate surroundings of the main city. Such situation occurs especially in the conurbation of Gdańsk and the agglomerations of Warszawa, Kraków and Poznań. This shows that the largest cities of Poland are the main engines of economic development by stimulating their surroundings and their impact on the surrounding areas. Unfortunately, the towns located in the marginal zones of several agglomerations (the zone $25-50 \mathrm{~km}$ away from the main city) experience certain disadvantages, such as the process of "the backwash effect". Furthermore, the lack of developmental impulses is observed in many medium-sized towns at the distance of 50-100 km from the main city of the agglomeration.
\end{abstract}

KEY WORDS: medium-sized towns, agglomerations, population dynamics, the level of socio-economic development, Poland

ARTICLE HISTORY: received 19 April 2016; received in revised form 8 August 2016; accepted 13 August 2016

\section{Introduction}

Urban agglomerations are complex settlement systems where the leading role is played by a large, or very large, city which organises the space around itself. Its influence causes significant changes in the suburban zone surrounding the big city (MICHALSKI \& SULIBORSKI, 1985; JAKÓBCZYK-GRYSZKIEWICZ, 1998). The advancement of urbanization is reflected in a gradual weakening of the growth of the city's population and the transfer of the largest demographic dynamics, first to its immediate surroundings (suburbanisation) and then to more and more remote areas of the agglomeration (de-urbanisation) (KLAASSEN \& PAELINCK, 1979). The course and evaluation of the process of suburbanisation in Poland are well presented in the literature related to the subject (LISOWSKI, 2005a,b; ZBOROWSKI \& PARYSEK, 2008; PAWLAK, 2012).

If the main city and its zone of influence are treated as a centre-periphery system, development of the surrounding towns will continue with varied intensity over time and in space depending on the strength of the undergoing processes of "the backwash effect" and infiltration (LISOWSKI, 2005b, TARKOWSKI, 2008). It can be assumed that 
the process will depend on the distance from the main city of the agglomeration. The further the town is located from the main city, the weaker its influence is.

A big city can stimulate, spur or restrain the growth of smaller centres in its surroundings through a more, or less, vital links with them. An increase of cohesion within such a settlement system, resulting from the intensification of links between its elements, leads to the formation of a metropolitan system (REGULSKI, 1980; KUCIŃSKI, 1990; SZYMAŃSKA, 2009). In such a system, the major city gradually transfers some of its residential features and some specialist ones specialized from traditional industrial activities and services (trade, transport) to other towns while the major city itself keeps the functions of management and control and provides high order services (MARKOWSKI \& MARSZAE, 2006; KUĆ-CZAJKOWSKA, 2014). Metropolitan areas reflect the range of the labour market and the housing market of large cities which are metropolitan centres (KoRCELLI-OLEJNICZAK, 2012; KUREK ET AL., 2014). Metropolitan centres may stimulate development of towns in the metropolitan area, but towns located outside the area may be at a greater risk from the "backwash effect". "Metropolitan settlement systems (agglomerations, conurbations, regions, urban or metropolitan areas) have a profound impact on the social and economic life of regions" (ZBOROWSKI, 2005b, p. 62), including regional settlement systems. The growing importance of metropolitan systems in Europe and the initiation of metropolization processes in Poland requires a consideration of the conditions for the development of medium sized towns located both within such systems and outside of them. Various opportunities and threats to urban growth of medium sized towns depend on their location in relation to the nearest metropolis were noticed by KUNZMANN (2000) who distinguished the following criteria:

- location within the metropolitan systems,

- location on the boundaries of such regions, or between them,

- and location on the periphery, outside of the systems.

Medium sized towns are the subject of this analysis, i.e. towns with a population between 20 to 100 thousand inhabitants, situated at a distance of up to $100 \mathrm{~km}$ from the main city of the agglomeration.

The aim of the article is to compare the level of population and economic development of medium sized towns located at different distances from the main city of the six largest metropolitan agglomerations and two conurbations in Poland. The analysis takes into account medium sized towns located within an agglomeration and medium sized towns located in the area surrounding the agglomerations (outside of the systems). Comparisons have been made for the years 1998 and 2013.

\section{Changes in the number of medium sized towns in urban areas and in their surroundings}

There is the same number of medium sized towns located at a distance of $100 \mathrm{~km}$ from the main city in each agglomeration system and its surrounding area within this study (Tab. 1):

- within the Warszawa agglomeration and its vicinity, there is a total of 20 medium sized towns,

- in metropolitan areas where the main city has a population in excess of half a million inhabitant, there are 12 to 16 medium sized towns,

- while the smaller agglomerations with the population of 250-500 thousand (Lublin, Gdańsk), the number of medium sized towns is equal to 11 . Only in the Katowice conurbation and its surrounding area, are there more than 25 such towns.

It should also be noted that the number of medium sized towns is variable. Some of the medium sized towns, with a population exceeding 20 thousand in 1998 (Pionki, Kozienice, Chodzież, Bieruń, Pyskowice, Łask, Łęczna, Krasnystaw) showed a decline in their population to less than 20 thousand inhabitants joining the group of small towns (as of 2013). While in 1998 Orzesze, Wieliczka, Trzebinia, Reda, Marki, Ząbki and Kobyłka, belonged to the group of small towns, in subsequent years these showed an increase in population to more than 20 thousand inhabitants and were moved to the group of medium sized towns in 2013. Only in Jastrzębie Zdrój, the population declined to less than 100 thousand and due to that the town moved from the group of large towns to the group of medium sized ones. To maintain comparability of the ranking of the towns in both investigated time ranges, the same set of the towns was taken into consideration even if in one of the time ranges a given city did not meet the criterion of a population of 20-100 thousand. 
Table 1. Medium sized towns in agglomeration systems and their surroundings - the number of towns (source: the author's study based on Local Data Bank of Central Statistical Office)

\begin{tabular}{|c|c|c|c|c|c|c|}
\hline \multirow{3}{*}{$\begin{array}{l}\text { Population of the } \\
\text { main city of the } \\
\text { agglomeration } \\
\text { (in thousands of } \\
\text { people) }\end{array}$} & \multirow{3}{*}{$\begin{array}{l}\text { Agglomerations and } \\
\text { conurbations } \\
\text { together with their } \\
\text { surrounding areas }\end{array}$} & \multirow[t]{3}{*}{ Years } & \multirow{2}{*}{$\begin{array}{l}\text { Total number } \\
\text { of medium } \\
\text { sized towns } \\
\end{array}$} & \multicolumn{3}{|c|}{$\begin{array}{l}\text { Distance from the main city of the } \\
\text { agglomeration in km }\end{array}$} \\
\hline & & & & Up to 25 & $25-50$ & $50-100$ \\
\hline & & & \multicolumn{4}{|c|}{ Number of towns } \\
\hline & & 1998 & 19 & 6 & 5 & 8 \\
\hline over 1000 & Warszawa & 2013 & 20 & 9 & 5 & 6 \\
\hline & & NOIT* & 22 & 9 & 5 & 8 \\
\hline \multirow{12}{*}{$500-1000$} & & 1998 & 16 & 4 & 8 & 4 \\
\hline & Łódź & 2013 & 15 & 4 & 7 & 4 \\
\hline & & NOIT $^{*}$ & 16 & 4 & 8 & 4 \\
\hline & & 1998 & 10 & 1 & 4 & 5 \\
\hline & Kraków & 2013 & 12 & 2 & 5 & 5 \\
\hline & & NOIT* & 12 & 2 & 5 & 5 \\
\hline & & 1998 & 16 & 2 & 6 & 8 \\
\hline & Poznań & 2013 & 15 & 2 & 6 & 7 \\
\hline & & NOIT $^{*}$ & 16 & 2 & 6 & 8 \\
\hline & & 1998 & 14 & 2 & 2 & 10 \\
\hline & Wrocław & 2013 & 14 & 2 & 2 & 10 \\
\hline & & NOIT* & 14 & 2 & 2 & 10 \\
\hline \multirow{9}{*}{$250-500$} & & 1998 & 11 & 3 & 3 & 5 \\
\hline & Lublin & 2013 & 9 & 2 & 2 & 5 \\
\hline & & NOIT $^{*}$ & 11 & 3 & 3 & 5 \\
\hline & & 1998 & 10 & 2 & 6 & 2 \\
\hline & Gdańsk & 2013 & 11 & 2 & 7 & 2 \\
\hline & & NOIT* & 11 & 2 & 7 & 2 \\
\hline & & 1998 & 25 & 12 & 9 & 4 \\
\hline & Katowice & 2013 & 25 & 12 & 9 & 4 \\
\hline & & NOIT $^{*}$ & 27 & 13 & 10 & 4 \\
\hline
\end{tabular}

NOIT*- the number of investigated towns (the same number of towns comparable for both time periods). It includes towns which had from 20 to 100 thousand inhabitants in at least one of the investigated time periods.

Settlement systems showing an increase in the number of medium sized towns in the years 1998-2013 were as follows:

a. Kraków agglomeration, where Wieliczka joined the group of medium sized towns and Trzebinia, located between the agglomeration of Kraków and Katowice conurbation, which population was about 20 thousand for many years;

b. Gdańsk conurbation (Tri-city) - where Reda exceeded the threshold of 20 thousand inhabitants.

Variability in the population, shown by an increase in the population of small towns, accompanied by a declining population of some medium sized towns were observed in:

1. Warszawa agglomeration where three towns (Marki, Ząbki, Kobyłka) grew to the level of medium sized towns but two others (Pionki, Kozienice), located farther away from Warszawa, already outside of the agglomeration system, were degraded becoming a small towns;

2. Katowice conurbation where two towns joined the group of medium sized towns (Orzesze belonging to the Katowice conurbation and Jastrzębie Zdrój belonging to another settlement system) and two towns (Bieruń and Pyskowice) left it.

A reduction in the number of medium sized towns occurred in the surrounding areas of the following agglomerations:

a. Lublin, where the population decreased in Łęczna and Krasnystaw,

b. Poznań, where Chodzież joined the group of small towns,

c. Łódź, where Łask joined the group of small towns.

3. Changes in the number of medium sized towns and their population depending on the distance from the main cities of the agglomeration

Apart from all the delimitations of the analysed metropolitan systems (SEALSKIN, 1989; GORZELAK ET AL., 2008; ŚLESZYŃSKI, 2013) the medium sized towns were analysed in three zones of distance from the main city of the agglomeration:

1. the first zone (inner), which is not farther than $25 \mathrm{~km}$ from the main city, is the immediate surroundings and belongs to the agglomeration, 
2. the second zone (outer) is located at a distance of 25 to $50 \mathrm{~km}$ from the main city. In the case of large cities it is their marginal zone, and in the case of smaller systems the zone is already outside the agglomeration;

3. the third zone (peripheral) is located at a distance of 50 to $100 \mathrm{~km}$ from the main city and includes medium sized towns located outside the agglomeration.

It has been observed that in each settlement system the main city is surrounded by medium sized towns located at different distances from the centre (Tab. 1).

Regarding Polish agglomerations, the surrounding ring of medium sized towns is "repelled" far beyond the agglomeration system. Most mediumsized cities are in fact located within a distance of
50-100 km from the main city. Such a long "shadow of the big city" occurs mainly in the case of Wrocław, but also in the case of Kraków, Lublin and Poznań (DoMAŃSKI, 1987). In the case of the Wrocław agglomeration, the vast majority of the medium-sized towns (10 out of 14 ones) are located at a considerable distance from Wrocław. The towns concentrate $71.6 \%$ of the total population of the medium - sized towns located within $100 \mathrm{~km}$ off the centre of the agglomeration (Tab. 2). However, it should be noted that in the years 1998-2013 the share of the population of medium-sized towns in the immediate vicinity of the main city increased, which is particularly visible in the case of Poznan and Kraków.

Table 2. Populations of medium sized towns by zones of the distance from the main city (source: the author's study based on Local Data Bank of Central Statistical Office)

\begin{tabular}{|c|c|c|c|c|c|c|}
\hline \multirow{3}{*}{$\begin{array}{c}\text { Population of the } \\
\text { main city of the } \\
\text { agglomeration } \\
\text { (in thousands of people) }\end{array}$} & \multirow{3}{*}{$\begin{array}{l}\text { Agglomerations } \\
\text { and conurbations } \\
\text { together with their } \\
\text { surrounding areas }\end{array}$} & \multirow{3}{*}{ Years } & \multirow{2}{*}{$\begin{array}{l}\text { Medium sized } \\
\text { towns in total }\end{array}$} & \multicolumn{3}{|c|}{$\begin{array}{c}\text { Distance from the main city of the } \\
\text { agglomeration in km }\end{array}$} \\
\hline & & & & Up to 25 & $25-50$ & $50-100$ \\
\hline & & & \multicolumn{4}{|c|}{ population in thousands } \\
\hline over 1000 & Warszawa & $\begin{array}{l}1998 \\
2013\end{array}$ & $\begin{array}{l}751,1 \\
806,7\end{array}$ & $\begin{array}{l}285,4 \\
345,8\end{array}$ & $\begin{array}{l}158,6 \\
166,4\end{array}$ & $\begin{array}{l}307,1 \\
294,5\end{array}$ \\
\hline \multirow{4}{*}{$500-1000$} & Łódź & $\begin{array}{l}1998 \\
2013\end{array}$ & $\begin{array}{l}729,8 \\
689,1\end{array}$ & $\begin{array}{l}176,3 \\
166,6\end{array}$ & $\begin{array}{l}408,9 \\
385,7\end{array}$ & $\begin{array}{l}144,6 \\
136,7\end{array}$ \\
\hline & Kraków & $\begin{array}{l}1998 \\
2013\end{array}$ & $\begin{array}{l}419,0 \\
405,5\end{array}$ & $\begin{array}{l}42,4 \\
45,6\end{array}$ & $\begin{array}{l}154,7 \\
146,5\end{array}$ & $\begin{array}{l}222,0 \\
213,4\end{array}$ \\
\hline & Poznań & $\begin{array}{l}1998 \\
2013\end{array}$ & $\begin{array}{l}591,1 \\
595,7\end{array}$ & $\begin{array}{l}49,1 \\
61,8\end{array}$ & $\begin{array}{l}201,6 \\
201,3\end{array}$ & $\begin{array}{l}340,4 \\
332,6\end{array}$ \\
\hline & Wrocław & $\begin{array}{l}1998 \\
2013\end{array}$ & $\begin{array}{l}612,0 \\
560,3\end{array}$ & $\begin{array}{l}70,8 \\
69,5\end{array}$ & $\begin{array}{r}102,9 \\
93,6\end{array}$ & $\begin{array}{l}438,3 \\
397,2\end{array}$ \\
\hline \multirow{3}{*}{$250-500$} & Lublin & $\begin{array}{l}1998 \\
2013 \\
\end{array}$ & $\begin{array}{l}455,9 \\
433,4 \\
\end{array}$ & $\begin{array}{l}86,8 \\
82,7\end{array}$ & $\begin{array}{l}112,7 \\
104,4\end{array}$ & $\begin{array}{l}256,3 \\
246,3 \\
\end{array}$ \\
\hline & Gdańsk & $\begin{array}{l}1998 \\
2013\end{array}$ & $\begin{array}{l}422,7 \\
434,0\end{array}$ & $\begin{array}{l}64,4 \\
66,8\end{array}$ & $\begin{array}{l}281,9 \\
292,8\end{array}$ & $\begin{array}{l}76,4 \\
74,4\end{array}$ \\
\hline & Katowice & $\begin{array}{l}1998 \\
2013\end{array}$ & $\begin{array}{l}1296,5 \\
1204,8\end{array}$ & $\begin{array}{l}688,9 \\
640,0\end{array}$ & $\begin{array}{l}446,1 \\
416,5\end{array}$ & $\begin{array}{l}161,5 \\
148,2\end{array}$ \\
\hline $\begin{array}{l}\text { Population of the main } \\
\text { city of the }\end{array}$ & $\begin{array}{l}\text { Agglomerations } \\
\text { and conurbations }\end{array}$ & & Medium sized & \multicolumn{3}{|c|}{$\begin{array}{l}\text { Distance from the main city of the } \\
\text { agglomeration in km }\end{array}$} \\
\hline agglomeration & together with their & Years & & Up to 25 & $25-50$ & $50-100$ \\
\hline (in thousands of people) & surrounding areas & & \multicolumn{4}{|c|}{ population in \% } \\
\hline over 1000 & Warszawa & $\begin{array}{l}1998 \\
2013\end{array}$ & $\begin{array}{l}100,0 \\
100,0\end{array}$ & $\begin{array}{l}38,0 \\
42,9\end{array}$ & $\begin{array}{l}21,1 \\
20,6\end{array}$ & $\begin{array}{l}40,9 \\
36,5\end{array}$ \\
\hline \multirow{4}{*}{$500-1000$} & Łódź & $\begin{array}{l}1998 \\
2013\end{array}$ & $\begin{array}{l}100,0 \\
100,0\end{array}$ & $\begin{array}{l}24,2 \\
24,2\end{array}$ & $\begin{array}{l}56,0 \\
56,0\end{array}$ & $\begin{array}{l}19,8 \\
19,8\end{array}$ \\
\hline & Kraków & $\begin{array}{l}1998 \\
2013\end{array}$ & $\begin{array}{l}100,0 \\
100,0\end{array}$ & $\begin{array}{l}10,1 \\
11,2\end{array}$ & $\begin{array}{l}36,9 \\
36,1\end{array}$ & $\begin{array}{l}53,0 \\
52,6\end{array}$ \\
\hline & Poznań & $\begin{array}{l}1998 \\
2013 \\
\end{array}$ & $\begin{array}{l}100,0 \\
100,0\end{array}$ & $\begin{array}{r}8,3 \\
10,4 \\
\end{array}$ & $\begin{array}{l}34,1 \\
33,8 \\
\end{array}$ & $\begin{array}{l}57,6 \\
55,8 \\
\end{array}$ \\
\hline & Wrocław & $\begin{array}{l}1998 \\
2013\end{array}$ & $\begin{array}{l}100,0 \\
100,0\end{array}$ & $\begin{array}{l}11,6 \\
12,4\end{array}$ & $\begin{array}{l}16,8 \\
16,7\end{array}$ & $\begin{array}{l}71,6 \\
70,9\end{array}$ \\
\hline \multirow{3}{*}{$250-500$} & Lublin & $\begin{array}{l}1998 \\
2013 \\
\end{array}$ & $\begin{array}{l}100,0 \\
100,0\end{array}$ & $\begin{array}{l}19,0 \\
19,1 \\
\end{array}$ & $\begin{array}{l}24,7 \\
24,1 \\
\end{array}$ & $\begin{array}{l}56,2 \\
56,8\end{array}$ \\
\hline & Gdańsk & $\begin{array}{l}1998 \\
2013 \\
\end{array}$ & $\begin{array}{l}100,0 \\
100,0\end{array}$ & $\begin{array}{l}15,2 \\
15,4 \\
\end{array}$ & $\begin{array}{l}66,7 \\
67,5 \\
\end{array}$ & $\begin{array}{l}18,1 \\
17,1\end{array}$ \\
\hline & Katowice & $\begin{array}{l}1998 \\
2013\end{array}$ & $\begin{array}{l}100,0 \\
100,0\end{array}$ & $\begin{array}{l}53,1 \\
53,1\end{array}$ & \begin{tabular}{|l}
34,4 \\
34,6
\end{tabular} & $\begin{array}{l}12,5 \\
12,3\end{array}$ \\
\hline
\end{tabular}

Note: The calculations for the same number of towns (comparable for both time periods). It includes towns which had from 20 to 100 thousand inhabitants in at least one of the investigated time periods 
Within a short distance (25-50 km), the ring of medium-sized towns surrounds the main town in the Łódź agglomeration and the conurbation of Gdańsk. The system of medium-sized towns in the outer zone of the Łódź agglomeration was stable (only Łask decreased its population below the threshold of 20 thousand inhabitants), while in the conurbation of Gdańsk, the growing number of medium-sized towns in that zone was observed in the investigated period (mainly due to Reda, which exceeded the threshold of the population criterion of 20 thousand inhabitants).

The Katowice conurbation is the one which has the highest number of medium-sized towns in the inner zone of the settlement system (RUNGE ET AL., 2014). Within the distance of $25 \mathrm{~km}$ from Katowice, there are 12 medium-sized towns, whose population constitutes $53.1 \%$ of the total population investigated in that particular system of mediumsized towns. The number of medium-sized towns decreased with distance from Katowice. In the outer zone $(25-50 \mathrm{~km})$ of the system, there are 9 such towns which constitute $34.4 \%$ of the total population of the medium-sized towns. Moreover, the zone partly overlaps the neighbouring settlement systems (Bielsko agglomeration, Rybnik conurbation). The fewest, only 4 medium - sized towns, are located at a distance of $50-100 \mathrm{~km}$ from Katowice and they comprise only $12.5 \%$ of the population of the medium-sized towns in the Katowice conurbation and its surrounding area. The system is quite stable because intensity of changes was similar in all zones (minimal population growth in the zone of 25 to $50 \mathrm{~km}$ compared to the zone of 50 to $100 \mathrm{~km}$ ). However, there is a large variability in terms of classification as a medium-sized town which meets the criterion of a population size within the range of $20-100$ thousand people. During the period 1998-2013, Bierun and Pyskowice did not fulfil the criterion and fell into the group of small towns and Orzesze increased its population and exceeded the threshold of 20 thousand inhabitants. A group of mediumsized towns in the $25-50 \mathrm{~km}$ zone of was joined by Jastrzębie Zdrój where the population had decreased below the threshold of 100 thousand inhabitants. The city is situated at a distance of approx. $40 \mathrm{~km}$ from Katowice, however, it belongs to the neighbouring conurbation of Rybnik. Hence, the inner zone of the medium-sized towns was joined by Orzesze and Bierun left this group. In the second zone, Pyskowice moved to the group of small towns and Jastrzębie Zdrój became a medium-sized town.

The Warszawa agglomeration is also an interesting case showing a dichotomy in the distribution of medium-sized towns (especially as far as the population is concerned) between the inner zone and the peripheral zone.

In most of the agglomerations (Kraków, Lublin, Poznań, Wrocław), medium-sized towns are usually just outside the agglomeration systems and surround the agglomerations forming an outer ring. These are the towns located at a considerable distance from the main city of the agglomeration within the zone of $50-100 \mathrm{~km}$.

\section{Population dynamics of the medium-sized towns}

The towns which are the main centres of the agglomerations differ not only in the size of their population, but also their dynamics of change. The largest increase in population was recorded in Warszawa, Kraków showed weaker dynamics and a stagnating population was observed in the case of Gdańsk. The other centres of the settlement systems showed a decline in their population the strongest was in Katowice and Łódź (Tab. 3).

The medium-sized towns located within the urban areas and their surroundings (Tab. 3 medium-sized towns in total) also showed different trends in the changes: population growth occurred in the medium-sized towns located around Warszawa and Gdańsk, a stagnant population was observed in the medium-sized towns surrounding Poznań and a regress of the population occurred in the surroundings of Kraków, Lublin and Łódź. However, the strongest decline in population took place in the medium-sized towns in the conurbation of Katowice and the Wrocław agglomeration (Fig. 1).

The rate of change varied in intensity in different zones of the distance from the main city. In the agglomerations of Poznań, Kraków and Warszawa, the largest increase in population was recorded in the medium-sized towns which were the closest to the main city (within the agglomeration). When the distance increased, the dynamics of the population of the medium-sized towns decreased, but with a varied intensity in different agglomerations. In the Warszawa agglomeration, a rapid growth in the population of the medium-sized towns in the closest surroundings of Warszawa was accompanied by weaker growth in populations of the medium-sized towns in the second zone and a significant decrease occurred in the population outside the urban area (in the peripheral area). However, in the Tri-City conurbation, there was a slight increase in the population both in the first and the second distance zones, whereas a population decline was observed in the medium-sized towns most distant from Gdańsk. 
Table 3. Dynamics of the populations of the medium-sized towns in the years 1998-2013 by distance zones (source: the author's study based on Local Data Bank of Central Statistical Office)

\begin{tabular}{|c|c|c|c|c|c|c|}
\hline \multirow{3}{*}{$\begin{array}{c}\text { Dynamics } \\
\text { of populations } \\
\text { of the main city } \\
\text { of the } \\
\text { agglomeration } \\
(1998=100)\end{array}$} & \multirow{3}{*}{$\begin{array}{l}\text { The main city } \\
\text { of the } \\
\text { agglomeration or } \\
\text { conurbation }\end{array}$} & \multirow{3}{*}{ Years } & \multirow{2}{*}{$\begin{array}{l}\text { Medium-sized } \\
\text { towns in total }\end{array}$} & \multicolumn{3}{|c|}{$\begin{array}{l}\text { Distance from the main city of the agglomeration } \\
\text { in km }\end{array}$} \\
\hline & & & & Up to 25 & $25-50$ & $50-100$ \\
\hline & & & \multicolumn{4}{|c|}{ Population dynamics $(1998=100)$} \\
\hline 106,6 & Warszawa & $\begin{array}{c}1998- \\
2013 \\
\end{array}$ & 107,4 & 121,2 & 104,9 & 95,9 \\
\hline 102,5 & Kraków & $\begin{array}{l}1998- \\
2013\end{array}$ & 96,8 & 107,6 & 94,7 & 96,1 \\
\hline 100,6 & Gdańsk & $\begin{array}{c}1998- \\
2013 \\
\end{array}$ & 102,7 & 103,7 & 103,9 & 97,3 \\
\hline 94,8 & Poznań & $\begin{array}{l}1998- \\
2013\end{array}$ & 100,8 & 125,7 & 99,9 & 97,7 \\
\hline 99,1 & Wrocław & $\begin{array}{l}1998- \\
2013\end{array}$ & 91,6 & 98,2 & 91,0 & 90,6 \\
\hline 96,4 & Lublin & $\begin{array}{l}1998- \\
2013\end{array}$ & 95,1 & 95,2 & 92,7 & 96,1 \\
\hline 88,2 & Łódź & $\begin{array}{l}1998- \\
2013\end{array}$ & 94,4 & 94,5 & 94,3 & 94,6 \\
\hline $\mathbf{8 8 , 0}$ & Katowice & $\begin{array}{l}1998- \\
2013\end{array}$ & 92,9 & 92,9 & 93,4 & 91,8 \\
\hline
\end{tabular}

Note: The calculations for a fixed number of towns (comparable for both time periods)

Colours: big increase, medium increase, small increase, stagnation, small decrease, medium decrease, big decrease

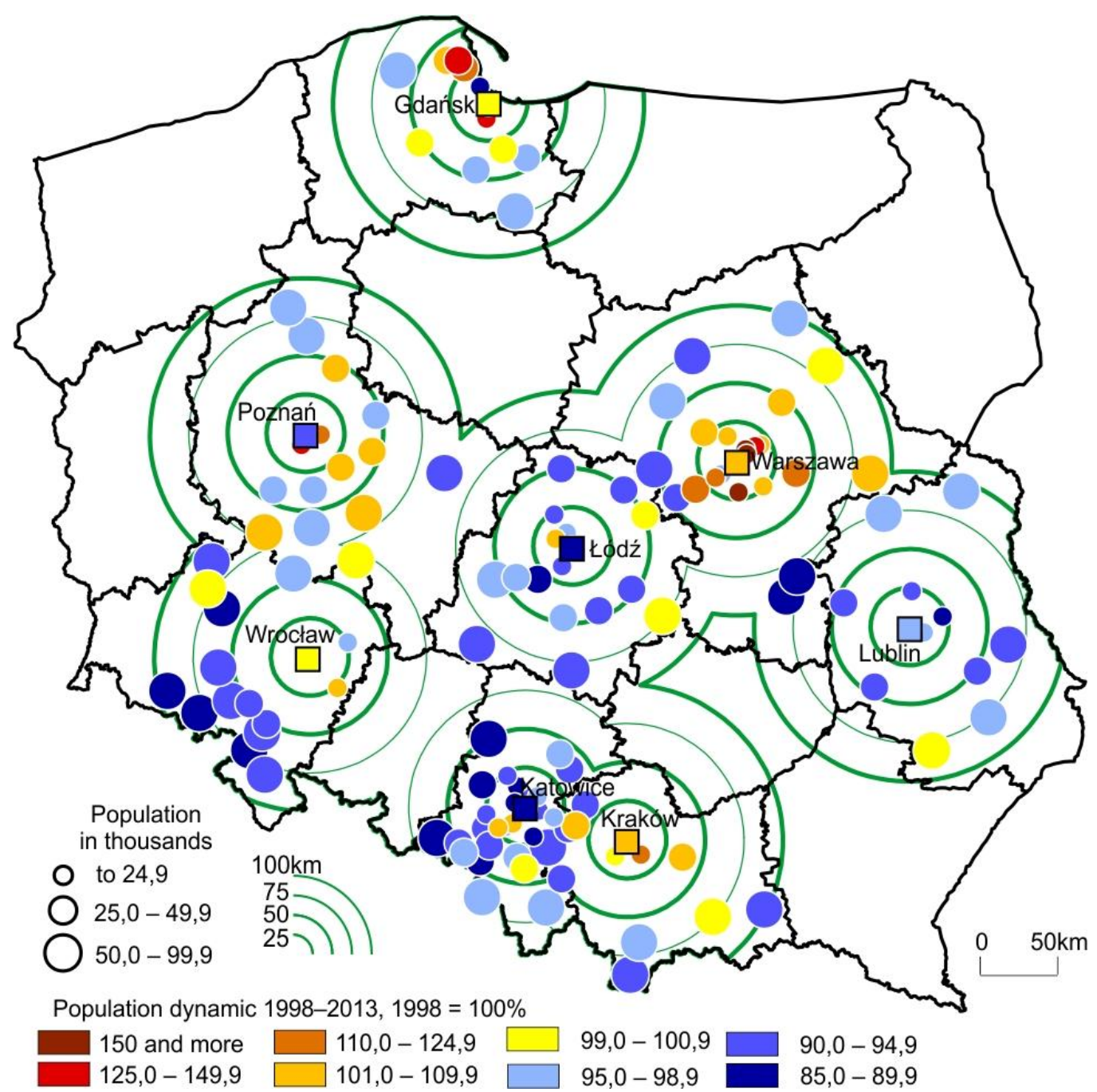

Fig. 1. Population dynamics of medium-sized towns in agglomeration systems and their surrounding areas - in the period 1998-2013 
A substantial increase in the population of medium-sized towns in the immediate surroundings of Poznań was accompanied by a stagnant population of the medium-sized towns in the second zone $(25-50 \mathrm{~km})$ and a decrease in the population of the most distant towns in that agglomeration. While in the surroundings of Kraków, the biggest decline in its population was observed in the second zone.

In the other investigated settlement systems, the central city of the agglomeration did not excite a population growth in the medium-sized towns in its surrounding area, neither in the closer nor the further away ones. Only in the Wrocław agglomeration, did the population decline in the medium-sized towns with distance from Wrocław (a slight decrease of population in the immediate zone and a substantial increase in the other distance zones). In the Łódź agglomeration, population decline in the medium-sized towns proceeded with a similar intensity in all the distance zones from Łódź. While in the Lublin agglomeration, there was a reverse trend in the population changes in the medium-sized towns in particular zones - the smallest decline in the population was recorded in towns most distant from Lublin, the largest - in the towns situated at a distance of $25-50 \mathrm{~km}$ from it. Thus, in the agglomerations of Lublin and Kraków, the zone of the most intensive "backwash effect" comprised of the medium-sized towns located at a distance of $25-50 \mathrm{~km}$ from the main city. However, in the Katowice conurbation, the decline in the population within $25-50 \mathrm{~km}$ from the main city was small compared to the other zones (though still strong). Various intensity of population changes in medium-sized towns, depending on the distance from the main city of agglomeration indicates that particular agglomeration systems are at different stages of the urbanization process, especially in the context of demography (RUNGE, 2011; WINIARCZYKRAŹNIAK \& RAŹNIAK, 2012; PANECKA-NIEPSUJ, 2013a). They do not always manifest a weakening of the centre for the benefit of the surroundings, as has been the case in the Poznan agglomeration. In the case of the Warszawa agglomeration, and the conurbation of Gdańsk, there is still a growth centre which stimulates development of the medium-sized towns not only in the immediate vicinity but also in the marginal zone. On the other hand, the zone of distance $25-50 \mathrm{~km}$ is already the zone of "the backwash effect" in the Krakow agglomeration. The beneficial impact of the central city on the towns in the immediate surroundings seems to be quite weak in the Wrocław agglomeration. Therefore, it can be stated that medium-sized towns located within agglomeration systems reflect positive changes in the population, while medium-sized towns situated outside the systems show a decrease in population. Lublin is an exception in that regard as the smallest reduction in the population occurred there in the towns furthest from Lublin. However, significant problems occur in the medium-sized towns in all the distance zones of Łódź and Katowice.

\section{Rank correlation index of the level of socio- economic development of medium-sized towns - research process methodology}

Changes in development of medium-sized towns in agglomeration systems depending on the distance from the main city of an agglomeration is illustrated by a rank correlation index calculated for the years 1998 and 2013. To construct it, the following factors were considered:

- birth rate per 1,000 people,

- net migration per 1,000 people,

- $\%$ of population of pre-working age in the whole population,

- \% of the population of post-working age in the whole population,

- dwellings completed per 1,000 people,

- entities of the national economy per 1,000 people,

- number of employed people per 1,000 people (in entities employing over 9 people).

Values for three of the above mentioned factors, i.e. natural growth, net migration and the number of completed dwellings, were calculated as the average of the three years: 1998 was the average value for the years 1997, 1998 and 1999 and for 2013 the average of the years 2012, 2013 and 2014 due to their large variability over time.

Considering these factors the ranking analysis of medium-sized towns was conducted for particular agglomeration systems (each one separately). Assuming these factors have a stimulant characteristic, the rank of 1 is for towns with the highest (most favourable) value. For the highest rank value (least favourable) for the non-stimulating factor ( $\%$ of population of post-working age), the last rank equal to the number of cities in the urban area was assumed. The sum of ranks for the studied factors indicates the level of development of the city as compared to other medium-sized towns in the particular urban area. The top positions in the ranking are occupied by towns with the lowest total of ranks, when the sum of ranks is higher the position of a given town is worse.

Summing the values of the ranks for towns in particular zones of distance from the main city 
and dividing the sum by the number of towns in each zone allowed a comparison of the mediumsized towns in each zone, both in terms of the level of their socio-economic development and their transformation. The lower the rank index is, the higher the level of population-economic development is. A low rank index indicates an improvement of the demographic situation and the labour market in a given town in comparison to other medium-sized towns.

\section{Rank correlation index of the level of socio- economic development of medium-sized towns by zones of distance from the main city in the agglomeration}

The calculated rank index (Tab. 4) shows that in 1998 in the conurbations (Gdańsk, Katowice) and in most of the agglomerations (Warszawa, Łódź, Krakow, Lublin) the highest level of socioeconomic development occurred in medium-sized towns located outside the settlement systems (zone distance of 50-100 km). In the agglomerations of Warszawa and Kraków and the Gdańsk conurbation, the medium-sized towns in the inner and outer zones had a similar level of socio-economic development, but lower than the one observed in the case of towns in the third zone. However, in the case of the Katowice conurbation and the Łódź agglomeration, the indices were the least favourable in towns in close proximity of the main city (zone 1) and improved with distance from it (the lowest rank index occurred in towns from the 50-100 km zone). In the Lublin agglomeration, the lowest level of development occurred in towns in the second zone.

The most favourable indices were observed only in the case of the medium-sized towns located within the Poznan agglomeration, but, the second zone was subject to washing out there.

Table 4. Rank index for medium-sized towns in different zones of distance from the main city of the agglomerations (source: the author's study based on Local Data Bank of Central Statistical Office)

\begin{tabular}{|c|c|c|c|c|c|}
\hline \multirow{3}{*}{$\begin{array}{l}\text { Agglomerations and } \\
\text { conurbations, } \\
\text { together with their } \\
\text { surroundings }\end{array}$} & \multirow{3}{*}{ Years } & \multirow{2}{*}{ Towns in total } & \multicolumn{3}{|c|}{ Distance from the main town of the agglomeration in $\mathrm{km}$} \\
\hline & & & Up to 25 & $25-50$ & $50-100$ \\
\hline & & \multicolumn{4}{|c|}{$\begin{array}{c}\text { rank index average for } 1 \text { town } \\
\text { (Comparable only within the given agglomeration) }\end{array}$} \\
\hline \multirow{2}{*}{ Katowice } & 1998 & \multirow[b]{2}{*}{27} & 110,1 & 90,8 & 76,8 \\
\hline & 2013 & & 100,5 & 98,1 & 89,3 \\
\hline \multirow{2}{*}{ Łódź } & 1998 & \multirow[b]{2}{*}{16} & 80,3 & 59,0 & 39,8 \\
\hline & 2013 & & 71,9 & 55,6 & 54,9 \\
\hline \multirow{2}{*}{ Gdańsk } & 1998 & \multirow{2}{*}{11} & 43,5 & 45,1 & 29,5 \\
\hline & 2013 & & 32,8 & 44,1 & 43,8 \\
\hline \multirow{2}{*}{ Kraków } & 1998 & \multirow{2}{*}{12} & 50,0 & 50,3 & 38,9 \\
\hline & 2013 & & 23,5 & 53,4 & 46,4 \\
\hline \multirow{2}{*}{ Lublin } & 1998 & \multirow{2}{*}{11} & 46,0 & 54,7 & 32,0 \\
\hline & 2013 & & 43,7 & 53,7 & 34,0 \\
\hline \multirow{2}{*}{ Poznań } & 1998 & \multirow{2}{*}{16} & 45,5 & 65,4 & 58,6 \\
\hline & 2013 & & 31,8 & 51,8 & 72,2 \\
\hline \multirow[b]{2}{*}{ Wrocław } & 1998 & \multirow[b]{2}{*}{14} & 52,5 & 55,5 & 51,9 \\
\hline & 2013 & & 34,0 & 53,3 & 56,1 \\
\hline \multirow{2}{*}{ Warszawa } & 1998 & \multirow{2}{*}{22} & 82,1 & 84,2 & 76,4 \\
\hline & 2013 & & 65,4 & 75,9 & 100,4 \\
\hline
\end{tabular}

Note: the lower the rank index, the higher the level of socio-economic development within the agglomeration; calculations for a fixed number of towns (comparable for the two time periods)

By 2013, all the medium-sized towns located within the investigated agglomeration systems (up to $25 \mathrm{~km}$ from the main city) had improved their socio-economic situation (significant decrease of the rank index). This indicates that those cities were the most strongly stimulated to develop and climbed to the top of the ranking of medium-sized towns in these analysed factors. In result, the best conditions were shown by towns in the first zone (internal) in the Poznań, Warszawa and Wrocław agglomerations and the Gdańsk conurbations in
2013. The situation of medium-sized towns located outside the agglomeration system - in the peripheral third zone worsened considerably. It was most clearly visible in the surroundings of the agglomerations of Warszawa, Wrocław, Gdańsk and Poznań, where the level of socio-economic development decreased significantly in the analysed factors (increase of the rank index) with increasing distance from the main city. As a result, the level of growth was highest in medium-sized towns in the first zone and lowest in the third zone. 
In the agglomerations of Kraków and Lublin the lowest level of development still occurred in the medium-sized towns of the second zone. In the case of the Kraków agglomeration a considerable improvement in the index was observed in the first zone, with further, but slight, deterioration of the indices of towns from the second zone and significantly worse development of towns in the third zone.

The medium-sized towns located within the agglomeration of Łódź and the Katowice conurbation (the first zone), were the most affected by the unfavourable effects of economic transformation due to their mono-function, and continued to show the weakest development index.

It would be too radical a simplification to state that the improvement in the medium-sized towns was proportional to the distance from the main city of the agglomeration, as the changes occurred with varying intensity within the determined distance zones.

HERBST \& WóJCIK (2013), treat metropolitan cities as the main centres of economic development, and determined the spatial range of the diffusion of development in the direction from the main cities to the surrounding regions. These authors also indicated which areas are characterized by particularly low levels of development due to their lack of functional links with main cities. The level of development relating to the income of municipality budgets: the size of their own revenues per capita for the years 2002-2010 were applied as a tool. "Delimitation of the areas of diffusion of economic development carried out by means of the method of spatial correlation at the municipal level has revealed that Warszawa, Poznań, Wrocław and the Katowice conurbation are the strongest centres of development diffusion in the global scale of their regions" (HERBST \& WóJCIK, 2013, p.19).

The results of the authors' research indicate that Warszawa is a development centre with the largest range of diffusion. "The area of its favourable impact on the surroundings is significantly greater than in other metropolitan cities (even approx. $40 \mathrm{~km}$ from the city centre), but it remains unsymmetrical. The diffusion of development from Warszawa is strongest in the western direction (approx. $40 \mathrm{~km}$ ), and least intensive in the eastern direction (approx. $20 \mathrm{~km}$ ). The municipalities revenues per capita outside the metropolitan area, reaching 30$40 \mathrm{~km}$ from the city centre, are significantly lower than the revenue of the main city and the municipalities located within the ring immediately surrounding the metropolis.... It indicates a significant polarization between the municipalities in the metropolitan area and the ones situated in its immediate vicinity. Nevertheless, it confirms the well-known rule from the regionalistic literature that units located just beyond the reach of functional links between the central city and the regional surroundings experience economic degradation and the backwash effect of their resources" (HERBST \& WójсIK, 2013, p. 14 and 15).

Also Poznań, Wrocław and Katowice have a positive impact on their revenue per capita in the immediate regional surroundings, although the extent of this impact is smaller than in the case of Warszawa. "In the Wielkopolska voivodeship, as well as in Mazovia, there is a polarization between the development of the metropolitan area of the capital of the voivodeship (Poznań) and the ring of municipalities directly outside the suburban zone of the metropolis" (HERBST \& WOJCIK, 2013, p.15).

The diffusion process of development of large cities does not occur in the eastern Polish voivodeships. Lublin is an urban centre not strong enough to become the development "locomotive" for more peripheral municipalities located within its own region (HERBST \& WOJCIK, 2013).

\section{Changes in the hierarchy of medium-sized towns in particular agglomeration systems}

Repositioning of medium-sized towns in particular zones of distance from the main city resulted from different intensities of the urbanization processes in different agglomeration systems. They were often the consequence of demographic factors arranged in a cause and effect sequence: the influx of migration, often accompanied by improvement of the housing stock caused by improvement of the age structure and sometimes even a slight improvement in the birth rate. However, in the Lublin agglomeration and the Katowice conurbation the pattern of change cannot be significantly observed.

There are only a few agglomerations (Warszawa, Kraków) and their surroundings with medium sized towns where improved population features were accompanied by a positive change in the labour market.

\subsection{The Warszawa agglomeration}

In 1989, the highest level of the studied features occurred in medium-sized towns situated outside the agglomeration system in the Warszawa agglomeration: Wyszków, lying at a distance of $50 \mathrm{~km}$ from Warszawa, and Ostrów Mazowiecka, Ostrołęka and Siedlce even further away. The favourable demographic situation of the towns resulted from: 
their relative demographic youth, higher birth rate than in other towns, and a well-developed regional labour market (the number of employed people). However, just below them, there were centres lying within the agglomeration, in close proximity to Warszawa: Marki, Piaseczno, Kobyłka, Ząbki (although three of them did not belong then to the group of medium-sized towns, because their population was lower than 20 thousand). The high position of the towns resulted from net migration and the developing residential infrastructure and the labour market rather than from the number of entities of the national economy than the number of employees.

However, in both of the areas they were also medium-sized towns with the lowest level of socio-economic development -Sochaczew, Pionki from the third zone and Legionowo, Piastów, Otwock from the first zone. Żyrardów, from the second zone, was last in the ranking.

The ranking of medium-sized towns which was quite varied spatially in 1998 was significantly ordered in subsequent years. In 2013, there were towns from the first zone (Piaseczno, Ząbki, Marki, Kobyłka) and from the second zone (Mińsk Mazowiecki and Grodzisk Mazowiecki) on top of the list. While the towns located outside the agglomeration, far from Warszawa, moved down the ranking (Ciechanów, Ostrów Mazowiecka, Ostrołęka) and some of them were degraded to a group of small cities (Kozienice, Pionki).

The most positive changes took place in Piaseczno which moved up from $6^{\text {th }}$ position to $1^{\text {st }}$ among the medium-sized towns of the Warszawa agglomeration and its further surroundings. By keeping a leading position in the labour market field, Piaseczno considerably improved its situation in terms of population growth and age structure. Ząbki which is attractive for housing investment has become one of the most important "bedrooms" of Warszawa. Because of this, Ząbki achieved a significant advance moving from $8^{\text {th }}$ to $2^{\text {nd }}$ in the ranking of medium-sized towns in all demographic factors. Population growth in Legionowo was also associated with investment in housing infrastructure, which enabled migration inflow. The improvement of Mińsk Mazowiecki, Grodzisk Mazowiecki and Nowy Dwór Mazowiecki in the rankings for medium-sized towns of the Warszawa agglomeration was not only due to the improvement of demographic factors, but also to improvement in the labour market. A large role in the rapid development of medium-sized towns was also played by a significant improvement in the accessibility of Warszawa by public transport and connecting roads (PANECKA-NIEPSUJ, 2013b).
Wyszków lost its high position in the ranking of medium-sized towns of the Warszawa agglomeration moving down to $8^{\text {th }}$ position. The stagnation in housing development did not stop migration outflow. There was also a decrease in business development, despite the fact that the workforce situation was better there than in many other medium-sized towns. Regress in the labour market in Ostrów Mazowiecka caused a deterioration in the characteristics of demographic dynamics and there was a decline of the city in the ranking from $2^{\text {nd }}$ place to $11^{\text {th }}$. Loss of the youth population also occurred in Ostrołęka.

\subsection{The Kraków agglomeration}

In the Kraków agglomeration, the towns which were highest in the ranking of medium-sized towns in 1998 were also situated outside the agglomeration and were located furthest from Kraków (Nowy Sącz, Nowy Targ, Gorlice, Zakopane), while among the towns located closer to Kraków there was only Bochnia from the second zone. Their high position was determined by a favourable population age structure and a well-developed housing infrastructure. The towns also created an important local labour market for their agricultural hinterland (Nowy Sącz, Gorlice) with a growing number of business entities (Zakopane, Nowy Targ).

In 2013, other towns, apart from Bochnia, from the immediate vicinity of Kraków (Wieliczka, Skawina), moved up to the top of the ranking of medium-sized towns. The most favourable changes took place in Wieliczka, which had just joined the group of medium-sized towns in the research period and even climbed up to $1^{\text {st }}$ position (from $8^{\text {th }}$ ) in the ranking of medium-sized towns in the Kraków agglomeration. Wieliczka maintained a positive level in terms of net migration and housing development, which resulted in a significant improvement in population growth (from $12^{\text {th }}$ position to $1^{\text {st }}$ ) and the percentage of the population in pre-working age. A high level of entrepreneurship enabled an increase in the number of people employed per 1,000 inhabitants. Also Skawina owed its advance from $9^{\text {th }}$ place to $3^{\text {rd }}$ due to favourable changes in the labour market.

Not as high as the towns from the inner zone were towns from the third zone (Nowy Sącz, Nowy Targ, Zakopane). The lowest level of development, just like in 1998, was still recorded in towns from the second zone, especially the ones located in the buffer zone between Kraków and the Katowice conurbation (Chrzanów, Oświęcim, Olkusz). The position of Gorlice (from $4^{\text {th }}$ to $8^{\text {th }}$ ) also declined as a result of the outflow of young people, the lack of improvement in housing and entrepreneurship. 


\subsection{The Katowice agglomeration}

The fact that the medium-sized towns from the core of the conurbation were at the bottom of the ranking (Czeladź, Będzin, Piekary Śląskie, Siemianowice Śląskie, Świętochłowice) was also a characteristic feature of the Katowice conurbation in 1998. Among the medium-sized towns within the conurbation, better positions were occupied by those located further, $20-25 \mathrm{~km}$, from Katowice (Mikołów and Łaziska Górne),while the best factors were presented by towns located just outside the conurbation: at a distance of $25-50 \mathrm{~km}$ from Katowice (Pszczyna, Czechowice-Dziedzice, Żory) and even further (Żywiec, Lubliniec, Cieszyn).

In 2013, the disproportions between towns from different zones equalized slightly. Top places were still occupied by towns from the second zone (Czechowice-Dziedzice, Pszczyna). However, positive changes helped to improve the position of towns from the second zone, slightly distant from Katowice (20-25 km - Orzesze, Bieruń, Mikołów, Łaziska Górne). Towns from the core of the conurbation: Czeladź, Siemianowice, Świętochłowice were still at the bottom of the ranking. Positive trends were observed in Będzin.

Among medium-sized towns located within the conurbation, Tarnowskie Góry achieved strong growth in the ranking of medium-sized towns of the conurbation - from $19^{\text {th }}$ to $7^{\text {th }}$, becoming an attractive place to live for people moving out from the large cities of the conurbation (RUNGE, 2015). There was a very large improvement in net migration and housing infrastructure. Orzesze advanced from $14^{\text {th }}$ places to $4^{\text {th }}$ in the ranking of medium-sized towns, by maintaining $1^{\text {st }}$ place in the field of migration, improvement of population growth and thus significantly weakening the ageing process. It was achieved, apart from other factors, due to the policy of local authorities which proposed a tax reduction for people settling in the town. Although the labour market there had not improved significantly, Orzesze had strong links with the labour markets of the neighbouring big towns. Whereas, Bierun reduced its population to a level below 20 thousand moving to the group of small towns. In spite of that, it moved up in the ranking of the investigated towns from $12^{\text {th }}$ to $5^{\text {th }}$ place by maintaining the leading position in the labour market. The relatively good condition of the local coal mines does not stimulate development of entrepreneurship.

The medium-sized towns which lost their position belonged to the second zone and were located outside the Katowice conurbation or even in neighbouring settlement systems (the conurbation of Rybnik) Wodzisław Śląski (from $13^{\text {th }}$ to $20^{\text {th }}$ place) and Jastrzębie Zdrój (9 $9^{\text {th }}$ to $18^{\text {th }}$ ). Decrease in the level of socio-economic development in relation to other medium-sized towns was also recorded in towns situated far away from Katowice (zone three), especially in Żywiec (3 $3^{\text {rd }}$ to $11^{\text {th }}$ position). Migratory outflow from those towns lasting since the 1990s contributed to a considerable deterioration of their position in terms of population growth. Ageing processes were more intensive in the towns belonging to the Rybnik conurbation (SiTEK ET AL., 2013). It is true that Wodzisław slightly improved its position in the fields of migration and housing, but the situation in the labour market became much worse. Whereas, Żywiec maintained a relatively stable situation in the labour market, it weakened its demographic dynamics due to slow housing development.

\subsection{The Gdańsk agglomeration}

In 1998, the highest level of socio-economic development was shown by towns from the second zone (Reda, Rumia) and third zone (Kwidzyn, Lębork) in the conurbation of Gdańsk. However, the other towns from the second zone were at the bottom of the ranking (Wejherowo, Malbork, Starogard Gdański, Tczew). The high position of Reda and Rumia resulted from a well-developed infrastructure, good housing and favourable demographic structures and demographic dynamics. While in towns located far from the core of the conurbation (Kwidzyn, Lębork) the assets were a good labour market and the demographic situation. In 2013, Pruszcz Gdański from the first zone and medium-sized towns from the second zone (Reda, Rumia) moved to top places in the ranking. The biggest advance of Pruszcz Gdański from $5^{\text {th }}$ to $1^{\text {st }}$ place resulted from improvement in the demographic supply, positive changes in its age structure and housing development. Wejherowo moved from $10^{\text {th }}$ to $5^{\text {th }}$ position by improving the coefficients of demographic dynamics and its age structure and slight improvement in the labour market.

The worse position of Lębork (drop from $4^{\text {th }}$ to $9^{\text {th }}$ ) resulted from migration outflow and thus reduced share of young people in the population.

\subsection{The Wrocław agglomeration}

The Wrocław agglomeration is very specific since the majority of the medium-sized towns are located at a distance of 50-100 km from Wrocław, which is beyond the agglomeration system. In 1998, the highest level of socio-economic development 
was recorded in Polkowice and Głogów, while the lowest one was in Bielawa and Nowa Ruda. Such a situation was caused by the situation in the labour market - in the first case, good condition of the copper industry and in the second one poor condition of coal mining and the textile industry.

In 2013, it was evident that Bielawa, Nowa Ruda, Kamienna Góra still had economic problems after the system transformation in Poland after 1989 (RUNGE, 2013) while the situation of the towns located closest to Wrocław (25 km) greatly improved. Oława, which already had had a good situation in terms of housing and entrepreneurship, moved up in the ranking of medium-sized towns from $4^{\text {th }}$ place to $1^{\text {st }}$. The migration inflow (from $11^{\text {th }}$ to $1^{\text {st }}$ place) and increase in the number of employed inhabitants, which allowed an improved demographic structure of the town, strongly contributed to the increased. Oleśnica recorded a significant increase in position moving from $12^{\text {th }}$ position to $5^{\text {th }}$. The town maintained a positive ranking in terms of its demographic factors due to housing development. There was also a slight improvement in the labour market. Świebodzice located a bit further away from Wrocław maintained a good level in terms of demographic coefficients due to the development of housing infrastructure. This allowed the town to move from $9^{\text {th }}$ position to $4^{\text {th }}$ among the medium-sized towns under the influence of the Wrocław agglomeration.

A clear decrease in the level of socio-economic development in relation to other medium-sized towns was recorded in Jawor which moved down from $5^{\text {th }}$ to $9^{\text {th }}$ place because of the lack of improvement in the labour market exacerbated migration outflow of young people. A slightly better situation in the labour market in Świdnica did not prevent migration outflow either and the town fell from $3^{\text {rd }}$ to $6^{\text {th }}$ position in the ranking of medium-sized towns located within $100 \mathrm{~km}$ of Wrocław.

\subsection{The Poznań agglomeration}

In the Poznań agglomeration, as in Warszawa, the highest level in the range of attributes taken for investigation was recorded in the selected towns located at various distances from the centre of the agglomeration in 1998. The place at the top of the hierarchy of the medium-sized towns was held by Swarzędz, located close to Poznań, but the next places belonged to Piła and Leszno located at a significant distance from the centre. Behind them, Śrem from the second zone appeared and then Konin and Jarocin from the third zone. The former provincial towns Konin, Piła,
Leszno (located outside the Poznań agglomeration) showed high levels of socio-economic development. Due to well developed regional labour markets and an extensive housing infrastructure, they were relatively attractive places for inflow of young people from the agricultural hinterland. Śrem located in the outer zone (25-50 km) showed favourable demographic parameters, but it had a slightly worse situation in terms of housing and a weaker labour market. Other towns from the second zone (Gniezno, Kościan) were at the bottom of the ranking being accompanied by some of the towns from the third zone (Chodziez, Krotoszyn, Rawicz). This rather spatially varied level of socio-economic development of medium-sized towns in 1998, was clarified in 2013.

The biggest advance among the medium-sized towns in the Poznań agglomeration (from 11 th to $1^{\text {st }}$ place) was recorded in Lubon which lies in the vicinity of Poznań which not only retained its high position in the fields of migration (1 $1^{\text {st }}$ place), infrastructure, housing and the number of entities (2nd place), but it significantly improved its population growth and age structure (from last place to $1^{\text {st }}$ ). Also other towns from the second zone strengthened their positions, mainly due to housing investments and improved net migration, and with it the age structure parameters. Those towns were: Wągrowiec progressing from $10^{\text {th }}$ place to $5^{\text {th }}$, Września advancing from $9^{\text {th }}$ position to $4^{\text {th }}$ and Środa Wielkopolska which moved from $7^{\text {th }}$ to $2^{\text {nd }}$ place due to a recovery in the housing and labour markets, which was accompanied by improvements in population growth and age structure. Positive changes were also observed in Gniezno and Krotoszyn.

On the contrary, the position of medium-sized towns located at a considerable distance from the Poznań agglomeration significantly worsened, and had also lost their administrative functions as the voivodeship capitals. Thus, the former provincial capitals, especially Konin which dropped from $5^{\text {th }}$ to $15^{\text {th }}$ and Piła which fell from $2^{\text {nd }}$ to $12^{\text {th }}$ position, recorded strong declines in their ranking of medium-sized towns. In Konin, due to insufficient development of residential infrastructure and the loss of its leading position in the labour market, the demographic supply was reduced and a reversed trend of migration was initiated, which in turn intensified the ageing process, whereas in Piła, there was insufficient development in housing infrastructure and the labour market. A drop in the ranking of medium-sized towns in the Poznań agglomeration was also recorded in Leszno, Śrem and Jarocin. 


\subsection{The Lublin agglomeration}

In 1998, the former voivodeship capitals (Biała Podlaska, Zamość, Chełm) as well as Biłgoraj and Łuków, towns which were located beyond the agglomeration system (in the third zone) and were the most distant ones from Lublin were relatively best developed in the Lublin agglomeration. Łęczna, located near Lublin, maintained a good position, although the situation in the labour market was not stable there. The lowest level of socio-economic development occurred in mediumsized towns in the second zone (Kraśnik, Puławy, Lubartów) and the first one (Świdnik).

In 2013, towns from the third zone still maintained their high position, though, Chełm reacted poorly to the loss of administrative functions. The lack of housing investment and outflow of young people resulted in adverse changes in the age structure. There had also been a considerable decrease of entrepreneurship. As a result, Chełm showed a decline in its ranking of medium-sized towns under the influence of the Lublin agglomeration and dropped from $6^{\text {th }}$ place to $10^{\text {th. }}$

Major changes took place in the first zone. Łęczna experienced a significant decline in its position as a result of the outflow of young people (from $3^{\text {rd }}$ to $11^{\text {th }}$ ) due to difficulties in its labour market (11 $11^{\text {th }}$ place) and the lack of housing investment. Migration inflow was directed to other towns in the closer surroundings of Lublin Świdnik and Lubartów. This trend was encouraged by residential investment and, to a lesser extent, by improvement in the labour market. Hence, these towns increased their position in the hierarchy of the medium-sized towns in the Lublin agglomeration.

\subsection{The Łódź agglomeration}

In 1998, clear spatial regularities in terms of the diversity of socio-economic development of the medium-sized towns could be observed in the Łódź agglomeration. The highest positions in the ordered rank were occupied by towns from outside of the agglomeration, from the third zone (Opoczno, Wieluń, Sieradz, Skierniewice). In the middle of the rankings, were towns situated outside the system, in the second zone (Bełchatów, Łask, Łowicz, Piotrków Trybunalski, Zduńska Wola), whilst the lowest level of socio-economic development was experienced in towns lying near Łódź (Ozorków, Pabianice, Aleksandrów Łódzki).

In 2013, the highest positions in the hierarchy of the medium-sized towns in the Łódź agglomeration were occupied by Skierniewice,
Piotrków Trybunalski, Aleksandrów Łódzki and Wieluń. Therefore, apart from towns distant from Łódź, some of the towns from the closer surroundings started to gain higher ranking positions. While Ozorków and Pabianice still remained in the last places in the 2013 ranking, Aleksandrów Łódzki advanced significantly leaping from $13^{\text {th }}$ place to $3^{\text {rd }}$. The increase of the number of completed dwellings contributed to an improvement in the age structure of the town population. Promotion of Piotrków Trybunalski from $8^{\text {th }}$ to $2^{\text {nd }}$ position also occurred due to investments in housing, which weakened the unfavourable trends in migration and natural movement. An increase in the ranking of medium-sized towns in the Łódź agglomeration (from $6^{\text {th }}$ to $9^{\text {th }}$ ) was also recorded in the case of Zduńska Wola. Whereas the decline in importance of Łask led to its transition to the group of small towns (less than 20 thousand inhabitants).

\section{Conclusions}

The analysis of the distribution of mediumsized towns in agglomeration systems and their levels of socio-economic development enables us to note the different stages of change which taking place within these systems.

Firstly - there is a significant difference in the distribution of medium-sized towns in relation to the main city in particular agglomeration systems manifested by:

a. a long "shadow of the metropolis" of Wrocław, Poznań, Lublin, Kraków, as the number of medium-sized towns increased with distance from the main city of the agglomeration;

b. a short "shadow of the metropolis" - the largest number of medium-sized towns is at a distance of $25-50 \mathrm{~km}$ from the main city of the settlement system (Gdańsk, Łódź);

c. the lack of " metropolis shadow" in the case of Katowice, as the number of medium-sized towns decreased with distance from the main city of the conurbation;

d. a dichotomy in occurrence of medium-sized towns - in the nearest and the farthest area away from the main town of the agglomeration, the rarer occurrence of such towns in the second zone (Warszawa).

Secondly- in the light of the population dynamics in the medium-sized towns it should be noted that four of the analysed settlement systems are developing significantly (Warszawa, Gdańsk, Kraków and Poznań). Population growth in the main city stimulates: 
- strong development of the medium-sized towns in the first zone, and also, but a little less, in the second zone (the Warszawa agglomeration);

- poor development of the middle-sized towns in both of the zones (the conurbation of Gdańsk);

- strong development of the medium-sized towns but only in the ones located within the agglomeration - in the first zone (Kraków, Poznań). However, this is accompanied by a decrease in the population of Poznań.

Populations of the medium-sized towns decreases in the third zone, especially in the Warszawa agglomeration, or in that of Kraków.

The other settlement systems experience smaller, or bigger, difficulties in terms of demographic changes. Population stagnation in Wrocław is accompanied by a decline in the populations of the medium-sized towns, increasing with distance from Wrocław. In other systems, there is a decrease in the population of the main city, which is especially strong in Łódź and Katowice, as well as in the medium-sized towns located in their closer and more distant surroundings.

Thirdly - considering a wider range of demographic and economic aspects, it should be noted that, at the end of the 1990s, the mediumsized towns located outside the agglomeration systems (at a distance of 50-100 km from the main city of the agglomeration) were at the higher level of socio-economic development than the others. The highest level of development of towns in the third zone occurred in the agglomerations of Warszawa, Kraków, Łódź and Lublin and in the conurbations of Gdańsk and Katowice. Most of the medium-sized towns in the third zone could develop their own local or sub-regional labour markets, and some of them even served as administrative voivodeship capitals. Hence, the decentralization of the country administration favoured the development of medium-sized towns, especially the ones located peripherally in relation to the main economic centres. The higher level of medium-sized towns in the first zone occurred only in the Poznań agglomeration and in that of Wrocław, the medium-sized towns in all the zones represented a similar level of development.

By 2013, the level of development of the mediumsized towns located outside the agglomeration system (in the third zone) had been reduced in those settlement systems and the level of development of the towns located within the agglomeration (the first zone) had significantly improved. This applies to the conurbation of Gdańsk and the agglomerations of Warszawa, Kraków, Wrocław, and also to Poznań. Similar directions of change were also initiated in the Łódź agglomeration. This proves that the largest cities of the country are the engines of economic development stimulating development in their surroundings and their impact in the surrounding areas is increasing. Unfortunately, several towns located in the marginal zone of the agglomerations (the zone 25-50 km away from the main city) experienced certain disadvantages, such as the process of "the backwash effect". Furthermore, the lack of developmental impulses is observed in many medium-sized towns surrounding the agglomeration systems (at a distance of 50-100 km). There are no major changes in the hierarchy of medium-sized towns in the Lublin agglomeration and the Katowice conurbation. This confirms the thesis of HERBST \& WóJCIK (2013) that Lublin does not produce conditions conducive to municipalities to allow them to achieve their own high revenues.

The medium-sized towns located in the immediate vicinity of the main city of an agglomeration grow mainly due to the fact that they perform a function as "a bedroom" for the large city. The proximity of a large city with a high quality urban space and a high standard of housing in the medium-sized town may cause an influx of people, regardless of the situation in the local labour market (Tarnowskie Góry, Orzesze, Ząbki, Legionowo, Luboń, Świebodzice).

The transfer of businesses from the main city to medium-sized towns in its surroundings is observed only in the agglomerations of Warszawa, Kraków and Wrocław. However, only a few towns take over part of the functions of the main cities (functional specialization within the region being metropolitized which would cause intensification of the cohesion of functional links). The infiltration process was initiated in the agglomerations of Warszawa, Kraków and Wrocław (Oława, Skawina, Wieliczka, Grodzisk Mazowiecki, Środa Wielkopolska). It is possible to maintain a high position in the labour market in some medium-sized towns (Piaseczno, Piotrków Trybunalski), however, it does not always prevent negative migration trends (Wyszków, Bieruń, Żywiec).

The exodus of young people is greatly enhanced in towns considerably away from the main centre of the agglomeration, which causes a rapid acceleration in the process of demographic ageing, stagnation in infrastructure investments and initiates "shrinking" of a town, especially when collapse of the local labour market occurs (Jastrzębie Zdrój, Konin, Ostrołęka). A significant decrease in the position of medium-sized towns in the third zone - the most distant from the main 
city of the agglomeration - was additionally worsened by the loss of administrative functions, which resulted in a lack of investment in infrastructure, a weakening of the labour market and resulted in increased migration outflow. Only in the surroundings of the Lublin agglomeration, did the towns from the third zone still maintain their high position among other medium-sized towns.

\section{References}

Domański R. 1987. Przestrzenna organizacja rozwoju regionalnego. Studia KPZK PAN t. XCIII, PWE Warszawa.

Gorzelak G., Jałowiecki B., Smętkowski M. 2008. Obszary metropolitalne w Polsce: problemy rozwojowe i delimitacja. Centrum Europejskich Studiów Regionalnych i Lokalnych (EUROREG), Uniw. Warszawski.

Herbst M., Wójcik P. 2013. Delimitacja dyfuzji rozwoju z miast metropolitalnych $\mathrm{z}$ wykorzystaniem korelacji przestrzennej. Studia Regionalne i Lokalne, 4 (54), Centrum Europejskich Studiów Regionalnych i Lokalnych (EUROREG), Uniw. Warszawski: 5-21.

Jagielski A. 1989. Aglomeracje miejskie i migracje stałe w systemie osadniczym Polski. [in:] Korcelli P., Gawryszewski A. (eds.) Współczesne przemiany regionalnych i lokalnych systemów osadniczych $w$ Polsce. Prace Geogr. IGiPZ PAN 152: 77-89.

Jakóbczyk-Gryszkiewicz J. 1998. Przeobrażenia stref podmiejskich dużych miast. Studium porównawcze strefy podmiejskiej Warszawy, Łodzi i Krakowa. Wyd. Uniw. Łódz., Łódź.

Klaassen L.H., Paelinck J.H.S. 1979. The future of large towns. Environ. Plan., A, 11: 1095-1104.

Korcelli-Olejniczak E. 2012. Region metropolitalny - pojęcie, struktura przestrzenna, dynamika. IGiPZ PAN Warszawa.

Kuć-Czajkowska K. 2014. Aglomeracje, obszary metropolitalne, metropolie - próba uporządkowania pojęć. [in:] KućCzajkowska K., Sidor M. (eds) Miasta, aglomeracje, metropolie - w nurcie globalnych przemian. Wyd. UMCS Lublin: 55-76.

Kunzmann K.R. 2000. Network Europe: A Europe City Region. [in:] Bekemanns L., Mira E. (eds) Civitas Europa - Cities, Urban Systems and Cultural Regions between Diversity and Convergence. Bruxelles: Peter Lang Verlag: 119-131.

Kurek S., Gałka J., Wójtowicz M. 2014. Wpływ urbanizacji na przemiany wybranych struktur demograficznych i powiązań funkcjonalno-przestrzennych $w$ Krakowskim Obszarze Metropolitalnym. Uniw. Pedag., Kraków.

Lisowski A. 2005a. Janusowe oblicze suburbanizacji [in:] Jażdżewska I. (ed.) Współczesne procesy urbanizacji i ich skutki. XVIII Konwersatorium Wiedzy o Mieście, Uniw. Łódzki, Łódź: 91-100.

Lisowski A. 2005b. Procesy centralizacji i decentralizacji w aglomeracji warszawskiej w latach 1950-2002. Prace $i$ Studia Geogr., UW, 35: 13-44.

Markowski T., Marszał T. 2006. Metropolie. Obszary metropolitalne. Metropolizacja, Problemy i pojęcia podstawowe. KPZK PAN Warszawa.
Michalski W., Suliborski A. 1985. Procesy urbanizacji w strefie podmiejskiej na przykładzie gminy Dobroń. Acta Univ. Lodz., Folia Geogr., 5.

Panecka-Niepsuj M. 2013a. Przestrzenne zróżnicowanie sytuacji demograficznej miast średniej wielkości w Polsce, [in:] Zborowski A. (ed.) Człowiek - Społeczeństwo - Przestrzeń, III, Myczkowce-Kraków: 63-84.

Panecka-Niepsuj M. 2013b, Dostępność przestrzenna miast średniej wielkości w Polsce. [in:] Sitek S. (ed.) „Stare $i$ nowe" problemy badawcze $w$ geografii społecznoekonomicznej", 5, PTG Oddz. Katowicki, UŚ Wydział Nauk o Ziemi: 173-190.

Pawlak H. 2012. Procesy suburbanizacji: rozwój czy regres terenów podmiejskich? [in:] Zborowski A. (ed.) Człowiek - Społeczeństwo - Przestrzeń, II, Myczkowce - Kraków: 107-118.

Runge A. 2011. Medium-sizedtowns in the context of size structural changes of towns in Poland [in:] Runge A., Kuczabski A. (eds) Medium-sized towns of Central-Eastern Europe in the period of economic system transformation and social changes. Kharkiv, Publ. House "ADNDU": 88-87.

Runge A. 2013. Rola miast średnich w kształtowaniu systemu osadniczego Polski. Uniw. Śląski, Katowice.

Runge A. 2015. Powiązania migracyjne miast średnich $w$ konurbacji katowickiej w latach 1999-2011. Studia Miejskie,18, Uniw. Opolski, Opole: 103-118.

Runge J., Kantor-Pietraga I., Krzysztofik R., Runge A. 2014. Model urbanizacji złożonych układów osadniczych w świetle procesu kurczenia się miast $\mathrm{w}$ Polsce - próba analizy krytycznej, [in:] Stryjakiewicz T. (ed.) Kurczenie się miast w Europie Środkowo-Wschodniej. Bogucki Wyd. Nauk., Poznań: 115-126.

Sitek S., Runge J., Kłosowski F., Runge A., Petryszyn J., Pytel S., Kurpanik M., Spórna T., Zuzańska-Żyśko E. 2013. Społeczno-gospodarcze oraz przestrzenne kierunki zmian regionalnego oraz lokalnych rynków pracy województwa śląskiego. SGP WSL, Uniw. Śląski, Sosnowiec.

Szymańska D. 2009. Geografia osadnictwa. PWN, Warszawa.

Śleszyński P. 2013. Delimitacja Miejskich Obszarów Funkcjonalnych stolic województw. Przegl. Geogr., 85, 2: 173-197.

Tarkowski M. 2008. Centra i peryferie rozwoju społecznogospodarczego Polski w okresie transformacji ustrojowej. Wyd. Bernardinum", Gdynia-Pelplin.

Winiarczyk-Raźniak A., Raźniak P. 2012. Migracje wewnętrzne ludności $w$ polskich obszarach metropolitalnych u progu XXI wieku. Wyd. Nauk. Uniw. Pedag. w Krakowie, Kraków.

Zborowski A. 2005a. Jak daleko polskiej urbanizacji do Europy? [in:] Jażdżewska I. (ed.) Współczesne procesy urbanizacji i ich skutki. XVIII Konwersatorium Wiedzy o Mieście, Uniw. Łódzki, Łódź: 57-74.

Zborowski A. 2005b. Przemiany struktury społecznoprzestrzennej regionu miejskiego $w$ okresie realnego socjalizmu i transformacji ustrojowej (na przykładzie Krakowa). IGiPZ UJ, Kraków. 